\title{
La colaboración Universidad-Empresa como elemento motivador. Un estudio de caso
}

\author{
Alejandro Escudero-Santana $\left(^{*}\right)$, Pablo Aparicio-Ruiz $\left({ }^{*}\right)$, Rafael Grosso-de-la-Vega ${ }^{*}$ ) \\ y María Rodríguez-Palero $\left(^{*}\right)$
}

(*) Grupo Ingeniería de Organización Escuela Técnica Superior de Ingeniería. Universidad de Sevilla (España)

\section{RESUMEN}

En la última década la universidad española ha sufrido una gran transformación debido al proceso de Bolonia, el cual buscaba acercar la Universidad a las necesidades sociales. Aun así, sigue existiendo un considerable gap entre los conocimientos adquiridos en las enseñanzas universitarias y las competencias reclamadas en el mercado laboral. Los grados en ingeniería, no están carentes de esta problemática, siendo muchos los estudiantes que muestran dificultades en el desarrollo de ciertas competencias apreciadas en los entornos profesionales. Este trabajo recoge la experiencia que vienen desarrollando un grupo de profesores del área de Organización de Empresas para fomentar la relación entre la Universidad y la empresa. Enmarcado dentro del Plan de Innovación Docente de la Universidad de Sevilla, la propuesta se fundamenta en: simulaciones empresariales y un ciclo de conferencias. Los resultados obtenidos pueden considerarse muy positivos.

Palabras Clave: universidad-empresa; innovación docente, desarrollo de competencias.

\section{Introducción}

El proceso de transformación llevado a cabo en las universidades españolas a través del proceso de Bolonia se ha fundamentado en dos grandes pilares: la convergencia de las titulaciones, con el objeto de facilitar el intercambio de titulados y la homogeneización de las titulaciones, y la adaptación del contenido de los estudios universitarios a las demandas sociales, con el objeto de mejorar la calidad de la formación y la competitividad de los egresados.

Después de una década de su puesta en marcha, la consecución de estos dos grandes objetivos ha tenido luces y sombras. En relación con la convergencia de las titulaciones, decir que su logro es cuanto menos cuestionable; el grado de homogenización de las titulaciones entre diferentes universidades es escaso, a veces incluso en la mera denominación de los títulos. En relación con el segundo objetivo Bolonia centraba el proceso de aprendizaje en el alumno, y en la capacitación de este para desarrollar competencias necesarias su ejercicio profesional. Diferentes factores han propiciado que el proceso de transformación universitaria no haya alcanzado todos los objetivos deseados:

- En muchas ocasiones la transformación ha sido superficial, sin existir un verdadero cambio de paradigma educativo.

- El cambio requiere de la predisposición del alumno a asumir la responsabilidad de su aprendizaje, no siempre existiendo tal circunstancia.
- Las metodologías que permiten este verdadero cambio (por ejemplo, la enseñanza basada en proyectos o la clase invertida) requiere de grupos de alumnos reducidos, circunstancia que no siempre ha sido posible por el coste que requiere en una coyuntura económica no favorable.

Todo esto ha provocado que el grado de conexión entre aula y empresa no sean todo lo estrecho que los planes desean. Diferentes estudios, encuestas y entrevistas (Accenture-Universia, 2007; Tuning Project, 2009) han puesto de manifiesto que existe una distancia entre los conocimientos adquiridos en las enseñanzas superiores y las competencias necesarias en el mercado laboral; hecho que ha sido puesto de manifiesto tanto por alumnos egresados como por profesionales.

En el marco de los grados en ingenierías el gap existente entre universidad y empresa ha sido menos significativo, dado que las escuelas de ingeniería han tenido una enorme tradición en transferencia de conocimiento a su entorno empresarial, situación de la cual se han beneficiado los alumnos, especialmente en los aspectos más técnicos de la transferencia. Un ejemplo de ello son los trabajos fin de estudios, muchos de ellos realizado en entornos o proyectos reales, o las horas de prácticas de laboratorio. Sin embargo, siguen existiendo determinadas competencias que frecuentemente son señaladas como carencias de los alumnos cuando estos inician su carrera profesional, por ejemplo: (a) la administración, gestión y control empresarial, (b) la dirección de proyectos, (c) la capacidad de trabajo en equipo, o incluso, (d) la autonomía y capacidad de autoaprendizaje. 
Con relación a los contenidos y competencias relacionados con la realidad empresariales, en todas las titulaciones de ingeniería en España existen asignaturas relacionadas con la empresa, lo cual pone de manifiesto que los planes formativos son conscientes de la importancia de que los alumnos adquieran competencias en estos aspectos. Igualmente existen asignaturas en materia de emprendimiento, promoviendo la formación necesaria para fomentar la auto-empleabilidad de los estudiantes. Sin embargo, muchos estudiantes no encuentran que este aprendizaje sea necesario y asumen las asignaturas mencionadas con una evidente falta de motivación (tal como lo concluyen las encuestas ad-hoc).

Además de esta circunstancia particular de las asignaturas relacionadas con la empresa dentro de los estudios universitarios en ingeniería, existen otras dificultades que afectan de modo general a todas las asignaturas (extraída de las reuniones de coordinación de las titulaciones). Por un lado, la falta de autonomía en el estudiante. Autonomía entendida como la capacidad de buscar, crear y compartir nuevas ideas o conceptos y tener capacidad crítica y espíritu emprendedor. Por otro lado, la dificultad para crear grupos donde se desarrolle un verdadero trabajo cooperativo. Fomentar el trabajo en equipo, es básico en el desarrollo de competencias sociales, dado que las compañías suelen trabajan en grupos interdisciplinarios donde estas habilidades son altamente valoradas (Gil-Montoya et al., 2009). Es importante señalar que aprendizaje autónomo y trabajo colaborativo no son conceptos contrapuestos sino conceptos complementarios (Gil-Montoya et al. 2007).

Aunque la motivación es una cuestión particular del individuo, del alumno es este caso, el profesorado puede fomentar la motivación de estos (Mas-Tous y Medinas-Amorós 2007). Por tanto, los profesionales de ámbitos académicos deben esforzarse por buscar la mejor manera de acortar la distancia entre universidad y empresa. No es una tarea fácil sino necesaria si lo que se busca es la excelencia universitaria.

En este contexto, un grupo de profesores del área de Organización de Empresas, apoyados con diferentes programas del II y III Plan Propio de docencia de la Universidad de Sevilla han desarrollado una metodología de enseñanza-aprendizaje que tiene por objetivo aumentar la competitividad de los estudiantes en competencias empresariales y financieras. Dicha metodología se fundamenta en:

- Fomento de la relación universidad-empresa.

- Autonomía del estudiante.

- Trabajo en equipo.

Para ello se desarrollan principalmente dos tipos de actividades: (a) trabajos que requieren de la interactuación con el tejido empresarial y (b) un ciclo de conferencias que son impartidas por egresados y profesionales de reconocido prestigio a lo largo del curso.

Este artículo se estructura en diferentes apartados donde se describe el contexto en el cual se ha desarrollado la intervención, se aborda la metodología desarrollada en profundidad prestando especial atención a su adaptación a las diferentes asignaturas, posteriormente se indica el proceso de adaptación en las diferentes asignaturas y por útlimo se presentan las conclusiones.

\section{Contexto}

La intervención objeto este trabajo fue en asignaturas impartidas en la Escuela Técnica Superior de Ingeniería de Sevilla. Aunque la mayor parte de la carga de la intervención cayó en profesores de dicha universidad, pertenecientes al departamento de Organización Industrial y Gestión de Empresas II, se contó con la colaboración de otros profesores pertenecientes al área de organización de empresas de diferentes universidades públicas españolas (Universidad de Extremadura, Universidad de Vigo, Universidad de Oviedo), como expertos que valorarán la experiencia. Un total de 20 profesores han participado de la experiencia.

La intervención se realizó en asignaturas de diferentes titulaciones, pudiéndose agrupar estas en varias categorías: Organización y Administración de Empresas (OAE), Emprendimiento y Creación de Empresas (ECE), Planificación y Control de la Producción. (PCP), Dirección de Proyectos (DP) y Experiencias personales y desarrollo profesional (EP)

Esta iniciativa viene desarrollándose durante la última década, pero con mayor intensidad en los últimos cuatro años y se ha financiado a través del II y III Plan Propio de Docencia de la Universidad de Sevilla.

\section{Metodología}

La metodología propuesta trata de acercar el currículo a las competencias propias del perfil profesional de salida. Yániz (2005) define competencia como "el conjunto de conocimientos, actitudes y destrezas necesarias para desempeñar una ocupación dada", es decir, la capacidad para realizar de forma adecuada un determinado problema o tarea. La formación de esta capacidad de actuar de manera eficaz implica, por un lado, ampliar el foco curricular tradicional, centrado en los conocimientos disciplinares, para incluir habilidades prácticas y actitudes y, por otro lado, enfatizar dentro del currículo la aplicación de esos conocimientos, habilidades y actitudes en contextos específicos (Perrenoud, 1998; Paricio et al. 2019)

La metodología desarrollada conlleva una doble vertiente, por un lado, traer el conocimiento y experiencia de la empresa al aula y, por otro, forzar que el alumno deba verse inmerso en la realidad empresarial e industrial antes de su salida de la universidad. Para ello, se han propiciado dos tipos de actividades:

- Ciclos de conferencias.

- Simulaciones de entornos empresariales.

Aunque muchas actividades desarrolladas son complementarias al transcurrir habitual de cada asignatura, se trata, siguiendo el planteamiento de Yániz (2015), de integrar las competencias genéricas como parte de los programas formativos. Dependiendo de la asignatura y actividad, esta puede tomar un carácter voluntario u obligatorio.

\section{Ciclos de conferencia}

Cada año se organiza un ciclo de conferencias donde profesionales transmiten su conocimiento y experiencia. Este ciclo de conferencias se compone de charlas, coloquios, mesas redondas y ponencias especializadas que se distribuyen durante todo el curso académico. A la hora de planificarlo, se tienen en cuenta los siguientes aspectos:

- Deben abarcar diferentes competencias profesionales, comprendiendo tanto aspectos transversales de cualquier titulación como otros más específicos.

- Las fechas de las distintas actividades deben distribuirse durante el curso.

- Las actividades pueden ser plenarias, sin ningún público objetivo específico, o pueden estar incluidas dentro de la planificación de una o varias asignaturas. 
- Se incentivará que los ponentes sean personas del contexto empresarial de la ETSI o alumnos egresados.

- Se busca que el elenco de ponentes sea diferente cada año, sobre todo en las actividades transversales.

El principal objetivo es garantizar una amplia variedad de temáticas, donde todos los alumnos de la ETSI puedan participar en las actividades que consideren interesante. Al variar muchos de los ponentes cada año, se amplía la oferta ofrecida a los alumnos a lo largo de sus cuatro años de formación.

Tabla 1

Actividades realizadas en el ciclo de conferencias durante un curso académico
A continuación, se presenta una lista de diferentes sesiones que se han ofrecido en un curso académico.

Estas ponencias además aportan credibilidad a la labor docente, relacionando estrechamente los contenidos expuestos en la asignatura con la realidad empresarial. Este favor favorece enormemente la motivación del estudiante. Martin et al. (1997) mostraron como los profesores creíbles se corresponden con estudiantes con niveles más altos de motivación.

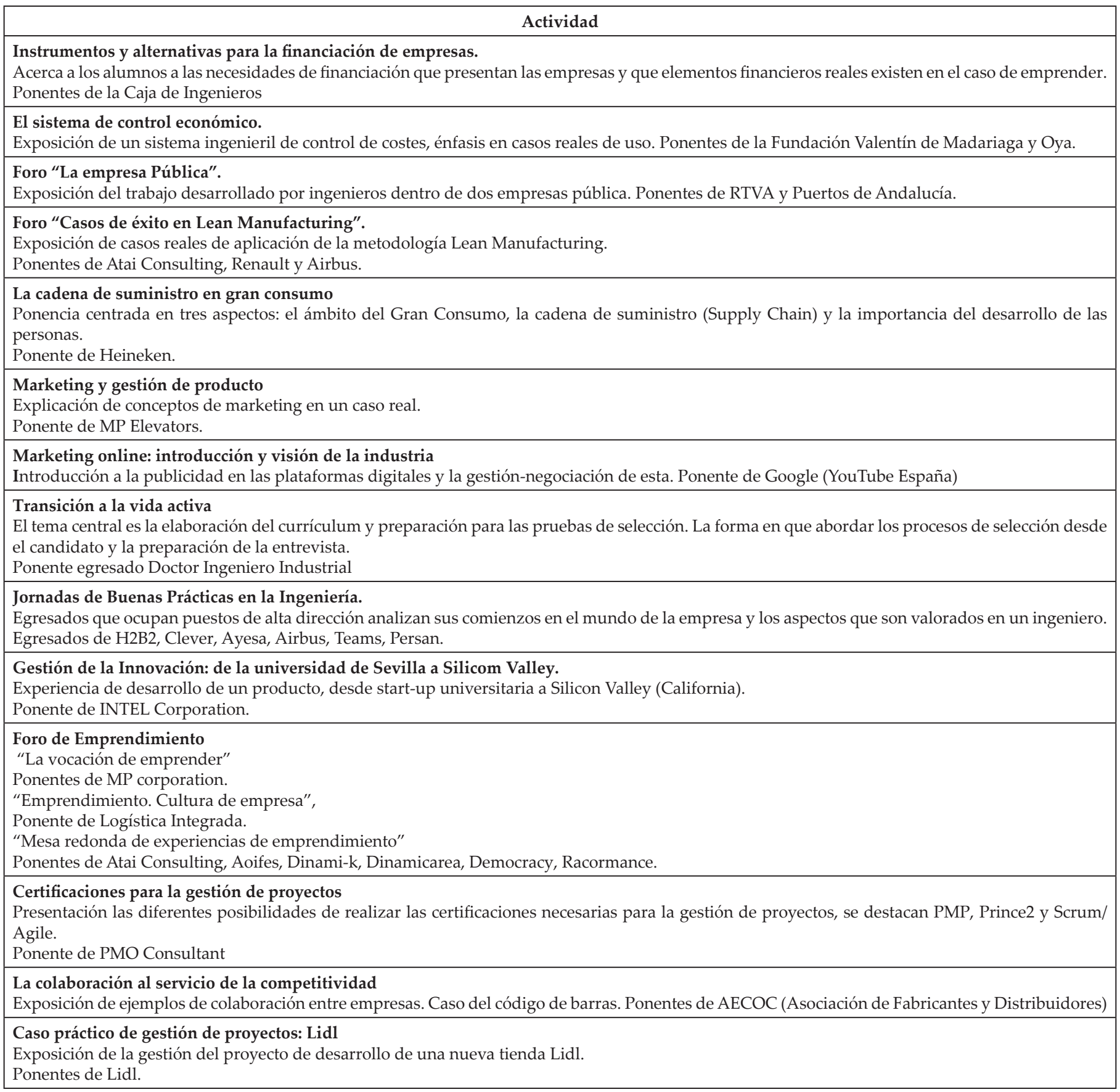




\section{Simulaciones de entornos empresariales}

En algunas asignaturas se diseñaron diferentes trabajos de simulación de entornos profesionales reales, donde los alumnos debían tomar decisiones ante las situaciones que iban aconteciendo. Estas simulaciones se han fundamentado en tres metodologías ampliamente conocidas: la autodidáctica (Rué, 2009), el aprendizaje basado en proyectos (Bell, 2010; Blumenfeld et al., 1991) y en la gamificación (Presnky, 2001).

A continuación, se muestran las principales actividades de simulación desarrolladas. Todas estas actividades se plantearon para desarrollarse en grupos colaborativos.

- Simulación de creación de empresas: En esta actividad se planteaba el objetivo de crear virtualmente una empresa. Para ello debían desarrollar una idea de negocio, valorar su aceptación, planificar su desarrollo, estudiar alternativas de formas jurídicas para la empresa, y buscar financiación.

- Desarrollo de un proyecto de inversión: Se les proporciona a los alumnos un proyecto real, para lo cual tienes que hacer un análisis de costes, buscar la financiación y estudiar la rentabilidad de la operación.

- Gestión de un proyecto: Se diseñaron varios juegos que permitían simular la gestión de un proyecto. En dichos juegos existen también determinados parámetros de riesgo. Búsqueda de financiación.

- Proyecto de mejora mediante metodologías Lean: Los alumnos debían visitar una empresa y hacer un análisis de desperdicios en la misma. Se planteaban propuestas de mejoras que posteriormente valoraban los responsables de las empresas y un tribunal de profesores.
- Desarrollo de la contabilidad de costes y análisis de balance: Los alumnos, a través de los estados financieros y de los informes del Sistema de Control Económico (contabilidad de costes) deben interpretar la situación que atraviesa una determinada empresa.

Algunas de estas experiencias han sido descritas pormenorizadamente en diferentes publicaciones (Escudero-Santana, 2015; Aparicio-Ruiz et al. 2019, Escudero-Santana et al. 2019; Montero et al. 2019).

\section{Resultados}

Los resultados de esta intervención se midieron desde 3 puntos de vista. Por un lado, la satisfacción de los alumnos con las actividades desarrolladas, por otro lado, la mejora en los resultados y, por último, la percepción de los profesores y ponentes externos.

La satisfacción de los estudiantes se midió a través de encuestas: tanto la obligatoria ofrecida por la universidad, como otros realizadas ad-hoc con el objeto de valorar las actividades desarrolladas. Todas las asignaturas implicadas en el proyecto han tenido una valoración por encima de la media del área y de sus titulaciones. La Figura 1 muestra los resultados obtenidos en las encuestas de satisfacción (sobre 5) de asignaturas que han participado en el proyecto, frente a la media del área, la titulación y la Universidad. La Tabla 2 muestra una encuesta ad-hoc realizada en el ámbito de una asignatura relacionada con la gestión de empresas para medir la valoración de los estudiantes respecto a estas metodologías. Los resultados muestran que los alumnos valoran positivamente este tipo de actividades.

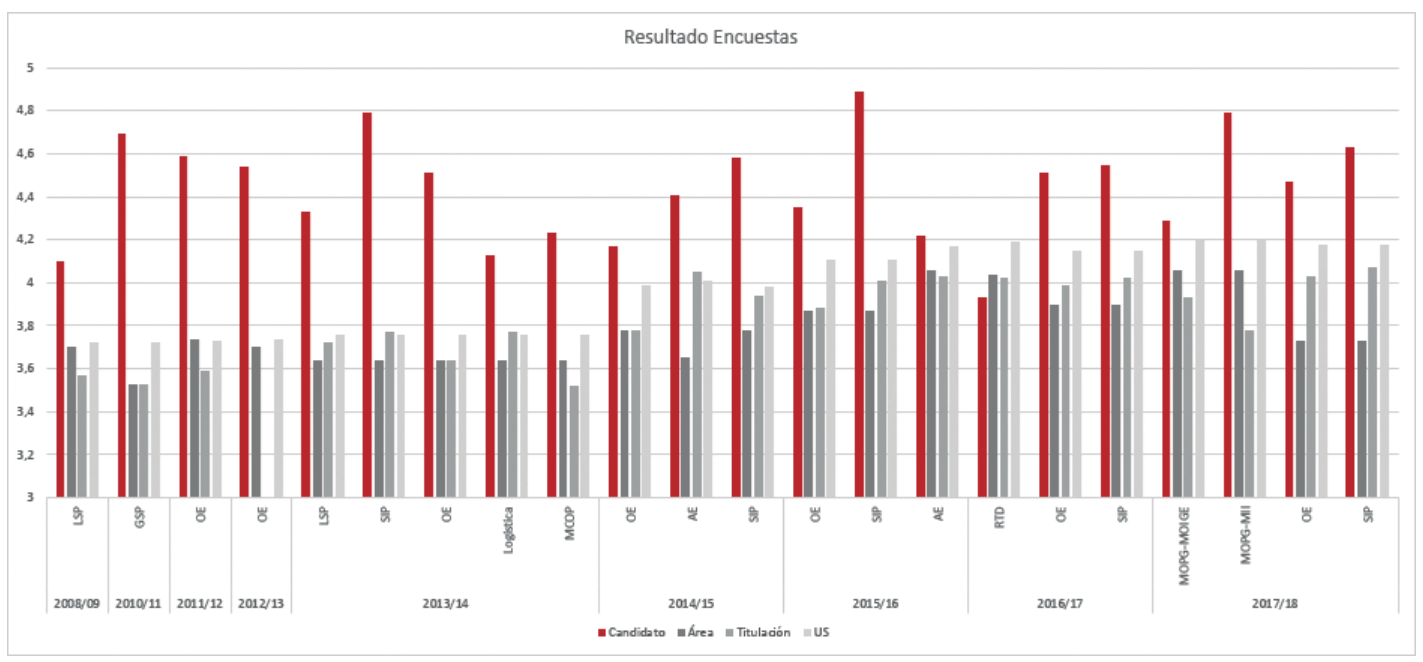

Figura 1. Encuestas de satisfacción de asignatura incluidas en el proyecto.

Tabla 2

Resultado de encuesta ad-hoc realizada a alumnos

\begin{tabular}{|c|c|c|c|c|c|}
\hline Pregunta \Valoración & 1 & 2 & 3 & 4 & 5 \\
\hline ¿Consideras interesante las ponencias de profesionales? & 1 & 0 & 5 & 15 & 39 \\
\hline ¿Te han ayudado a alcanzar los objetivos de la asignatura las ponencias? & 1 & 3 & 2 & 20 & 34 \\
\hline ¿Te han ayudado a alcanzar los objetivos de la asignatura el simulacro de empresa? & 1 & 0 & 2 & 12 & 45 \\
\hline ¿Consideras importante seguir con esta metodología? & 1 & 0 & 1 & 10 & 48 \\
\hline
\end{tabular}


En relación con los resultados de los alumnos, mencionar dos aspectos importantes: el índice de presentados y la calificación final. Para poder valorar la incidencia de la intervención en este aspecto, se han comparado (ver Figura 2) los resultados de primera convocatoria de dos asignaturas del ámbito de la gestión de empresas cuyos proyectos docentes comparten muchas similitudes, al tratar los mismos contenidos, pero en dos titulaciones diferentes. La asignatura 1 ha formado parte de la intervención mientras que la asignatura 2, debido al volumen de alumnos (ver Figura 2a), no ha participado plenamente. Analizando los resultados mostrados en la Figura $2 b$, se puede observar como el número de alumnos no presentados en la asignatura 1, es significativamente más bajo (un 17\% en la asignatura 1 frente al 50\% de la asignatura 2). Igual comparación puede establecerse en el número de aprobados en primera convocatoria.
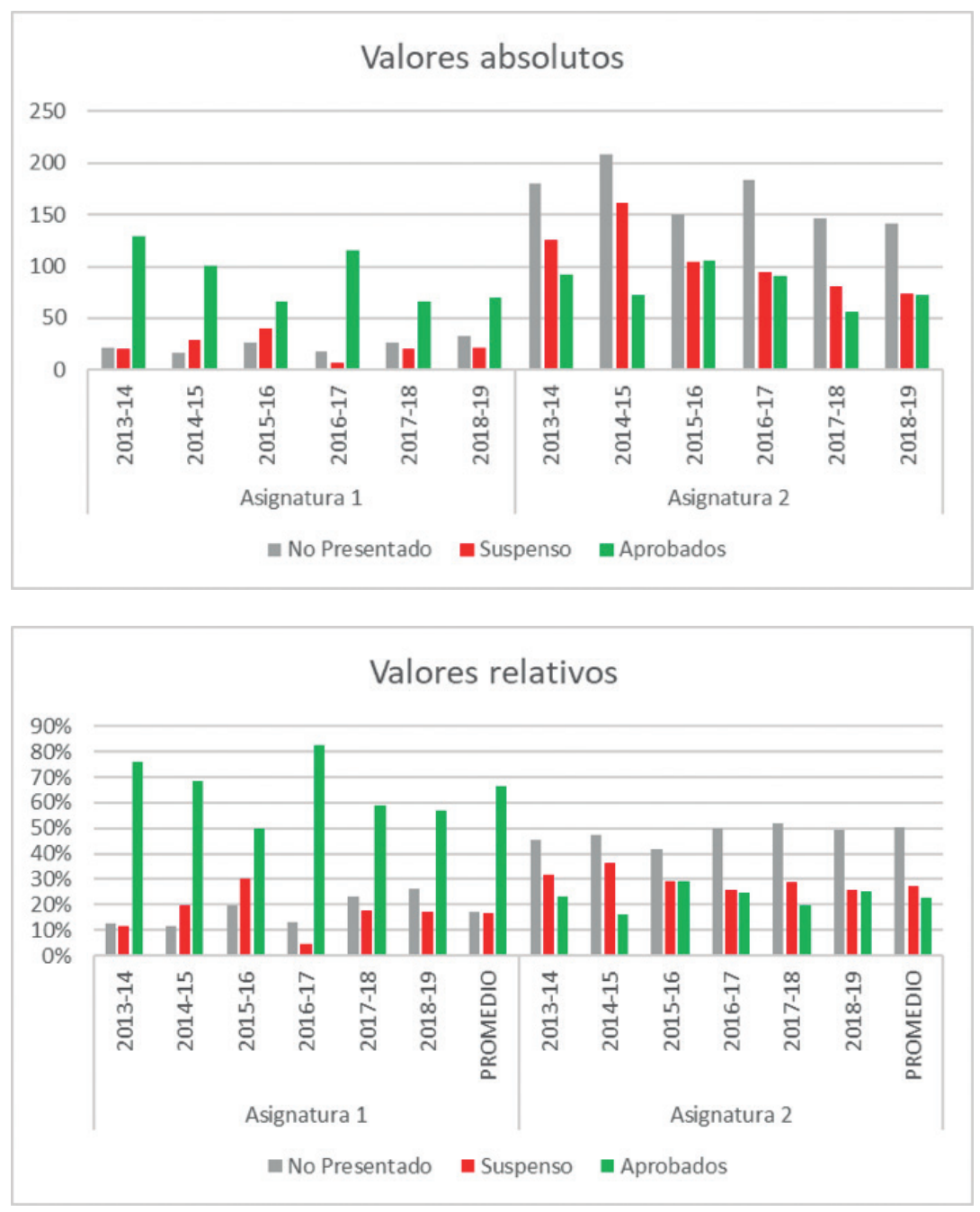

Figura 2. Comparativa de los resultados

El tercero de los aspectos que fue tenido en cuenta para la valoración de esta intervención académica fue la propia percepción de los profesores y ponentes externos. Para llevar a cabo esta medición al final de cada curso se establece una reunión de coordinación donde se debaten todas las cuestiones relativas a la metodología seguida, y se analiza el feedback de los estudiantes y de los ponentes invitados. Las principales valoraciones de estas reuniones han sido:

- Este tipo de actividades ha tenido una valoración muy positiva. Los alumnos valoran enormemente estas actividades, y el grado de implicación de estos llega a superar las expectativas.

- Los ponentes externos han puesto de manifiesto la nece- sidad de desarrollo de estas actividades, y su valoración sobre los resultados alcanzados ha sido muy positiva. Es una afirmación generalizada que los ponentes que este tipo de actividades favorece enormemente la formación de los estudiantes y su posterior inserción en el mercado laboral.

- Los profesores han percibido una mayor motivación de los estudiantes, lo que conlleva una mayor implicación con su propio proceso de aprendizaje.

- Todos los profesores implicados en la intervención coinciden en la alta demanda temporal requerida por este tipo de actividades. Que hacen que lleguen a ser impracticables, por lo menos de forma plena, cuando el grupo de estudiantes es muy numeroso. 


\section{Conclusiones}

En las titulaciones de ingeniería las asignaturas relacionadas con la gestión empresarial suelen enfrentarse a una falta generalizada de motivación por parte de los estudiantes. Para revertir esta situación, en la Escuela Técnica Superior de Ingeniería se viene desarrollando un proyecto de innovación docente que vincula los contenidos de diferentes asignaturas con experiencias profesionales reales. Para ello se han diseñado dos tipos de actividades, unos ciclos de conferencias que acercan profesionales al aula y proyectos de simulación empresarial, que busca un enfoque más práctico y autónomo al proceso de aprendizaje.

El ciclo de conferencias cuenta con ponentes de diferente índole, que tratan de contar su experiencia profesional y las necesidades del mercado, desde una perspectiva multidisciplinar. Las ponencias que cada año se definen tratan de cubrir diferentes ámbitos, que van desde el desarrollo de competencias menos presentes en el currículo de las titulaciones implicadas, hasta la empleabilidad relacionada con las nuevas tecnologías emergentes. Estos ciclos han logrado motivar a los alumnos en la necesidad de ser competentes es competencias relacionadas con la organización de empresas, permitiendo una mayor predisposición del estudiante en el aula.

Dado que el factor más determinante en el proceso de aprendizaje es aquello que el estudiante hace, se diseñaron estrategias de enseñanza que favorecían la participación activa del estudiante. Los proyectos de simulación empresarial permitieron que los estudiantes desarrollaran mecanismos de aprendizaje más profundos, facilitándose la interconexión de conceptos.

Los resultados obtenidos, tanto en términos de resultados académicos como satisfacción del alumnado han sido muy positivos, aunque no han estado exentos de dificultades. Tanto el grado de implicación de los estudiantes, reflejado en un aumento del índice de presentados, como los resultados académicos obtenidos, permiten confirmar dicha afirmación. 


\title{
The University-Business collaboration as a motivating element. A case study
}

\author{
Alejandro Escudero-Santana $\left(^{*}\right)$, Pablo Aparicio-Ruiz $\left(^{*}\right)$, Rafael Grosso-de-la-Vega $\left(^{*}\right)$ \\ y María Rodríguez-Palero $\left(^{*}\right)$ \\ $\left(^{*}\right)$ Organization Engineering Group Higher Technical School of Engineering. University of Seville (España)
}

\begin{abstract}
In the last decade, the Spanish university has undergone a great transformation due to the Bologna process, which sought to bring the University closer to social needs. Even so, there is still a considerable gap between the knowledge acquired through university teaching/ higher education and the skills demanded in the labor market. Engineering degrees share this problem too, with many students showing difficulties in the development of certain skills valued in professional environments. This work gathers the experience that a group of professors of the Business Organization area has been developing to foster the relation between the University and companies. Framed within the Teaching Innovation Plan of the University of Seville, the proposal is based on: business simulations and a series of lectures. The results obtained can be considered very positive.
\end{abstract}

Keywords: university-business; teaching innovation; skills development.

\section{Introduction}

The transformation process carried out in Spanish universities through the Bologna process has been based on two main pillars: the convergence of degrees, with the aim of facilitating the exchange of graduates and the homogenization of degrees, and the adaptation of the content of university studies to social demands, with the aim of improving the training standards and graduates' competitiveness.

After a decade of its implementation, these two main objectives have not been fully achieved. In relation to the convergence of degrees, it must be said that their achievement is at least questionable; the degree of homogenization of degrees among different universities is scarce, sometimes even in the mere denomination of degrees. Regarding the second objective, Bologna focused the learning process on the student and on their ability to develop the necessary competences for professional practice. Different factors have caused that the process of university transformation has not achieved all the desired objectives:

- On many occasions, the transformation has been superficial, without a real change of the educational paradigm.

- The change requires students to be willing to take responsibility for his or her learning, and such circumstance does not always occur.

- The methodologies that allow this real change (e.g. project-based learning or flipped classroom) require small groups of students, a circumstance that has not always been possible because of the ensuing cost, given the unfavorable economic climate.

As a result, the degree of connection between the classroom and the company is not as tight as the plans intended. Different studies, surveys and interviews (Accenture-Universia, 2007;
Tuning Project, 2009) have shown that there is a gap between the knowledge acquired in higher education and the skills required in the labor market; a fact that has been highlighted by both graduates and professionals.

Within the framework of engineering degrees, the gap between university and businesses has been less significant, given that engineering schools have had an enormous tradition in knowledge transfer to their business environment, a situation from which students have benefited, especially in the more technical aspects of transfer. An example of this are the projects at the end of their studies, many of which have been carried out in real environments or projects. Another instance is the amount of hours of hands-on work at the laboratory. However, there are still certain skills that are often identified as shortcomings of students when they start their professional careers, for example: (a) business administration, management and control, (b) project management, (c) teamwork capacity, or even (d) autonomy and self-learning capacity.

Concerning the contents and competences related to business reality, there are subjects related to business in all engineering degrees in Spain, which shows that the training programs are aware of the importance of students acquiring competences in these aspects. There are also subjects on entrepreneurship, promoting the necessary training to encourage self-employment of students. However, many students do not find that this learning is necessary and assume the subjects mentioned with an evident lack of motivation (as concluded by the ad-hoc surveys).

In addition to this particular circumstance of businessrelated subjects within university engineering studies, there are other difficulties that generally affect all subjects, as drawn from degree coordination meetings. On the one hand, the lack of autonomy in the student. Autonomy as the ability to seek, create and share new ideas or concepts and to have critical skills and an entrepreneurial spirit. On the other hand, the difficulty to create groups where a true cooperative work is developed. Encouraging teamwork is basic in the development of social skills, given that 
companies usually operate around interdisciplinary groups where these skills are highly valued (Gil-Montoya et al., 2009). It must be noted that autonomous learning and collaborative work help each other rather than working against one another (GilMontoya et al., 2007).

Although motivation is a particular question of the individual, in this case, of the student, the teaching staff can encourage the motivation of the student body (Mas-Tous and Medinas-Amorós, 2007). Therefore, professionals in academic environments should strive to find the best way to shorten the distance between university and business. It is not an easy task, but a necessary one if university excellence is the goal.

In this context, a group of professors of the Business Organization area, supported by different programs of the II and III training programs of the University of Seville, has developed a teaching-learning methodology that aims to increase the competitiveness of students in business and financial skills. This methodology is based on:

- Fostering of the university-industry relationship.

- Student autonomy.

- Teamwork.

Two main types of activities are developed for this purpose: (a) projects that require interaction with the business fabric and (b) a series of lectures given by graduates and professionals of renowned prestige throughout the course.

This work is divided into 5 chapters. Chapter 2 describes the context in which the intervention took place. Chapter 3 describes the methodology developed in depth and how it has been adapted to different subjects. Chapter 4 shows the results achieved in recent years. Chapter 5 concludes the work.

\section{Context}

The intervention analyzed in this work was performed in subjects taught at the Higher Technical School of Engineering (ETSI) of the University of Seville. Although most of the work of the intervention was carried out by the professors from said university belonging to the Department of Industrial Organization and Business Management II, other professors belonging to the business organization area of different Spanish public universities (University of Extremadura, University of Vigo, University of Oviedo) collaborated as experts who will value the experience. A total of 20 professors have participated in the experience.

The intervention was performed in subjects of different degrees, which can be grouped into several categories: Business organization and management (OAE), Entrepreneurship and enterprise creation (ECE), Production planning and control $(\mathrm{PCP})$, Project management (DP) and Personal Experiences and professional development (EP).

This initiative has been implemented during the last decade, but with greater intensity in the last four years, and has been financed through the II and III training programs of the University of Seville

\section{Methodology}

The proposed methodology aims to bring the curriculum closer to the competences of the graduates' professional profile. Yániz (2005) defines competence as "the set of knowledge, attitudes and skills necessary to perform a given occupation," that is, the ability to adequately fulfil a given problem or task.
The training for this capacity to act effectively implies, on the one hand, broadening the traditional focus of the curriculum, centered on disciplinary knowledge, to include practical skills and attitudes, and, on the other hand, emphasizing within the curriculum the application of those knowledge, skills and attitudes in specific contexts (Perrenoud, 1998; Paricio et al., 2019).

There are two sides to the developed methodology, on the one hand, bringing the knowledge and experience of businesses into the classroom and, on the other, forcing the student to immerse in the business and industrial reality before leaving the university. To this end, two types of activities have been promoted:

- Series of lectures.

- Business environment simulations.

Although many of the developed activities are supplementary to the normal course of each subject, the goal is to integrate generic competences as part of the training programs, following the approach of Yániz (2015). Depending on the subject and activity, the latter may be voluntary or compulsory.

\section{Series of lectures}

Each year a series of lectures is organized, where professionals pass on their knowledge and experience. This series of lectures is composed of talks, colloquiums, round tables and specialized lectures that are distributed throughout the academic year. When planning it, the following aspects are taken into account:

- They must cover different professional competences, including both transversal aspects of any degree and ones that are more specific.

- The dates of the different activities must be distributed throughout the course.

- The activities can be plenary, without any specific target audience, or they can be included in the planning of one or several subjects.

- It will be encouraged that speakers come from the ETSI business context or are former students.

- It is intended that the list of speakers be different each year, especially in the transversal activities.

The main objective is to ensure that a wide variety of topics is covered, so all ETSI students can participate in the activities they find interesting. As many of the speakers change each year, the offer proposed to students throughout their four years of education is expanded.

The following is a list of different sessions that have been offered in an academic year.

These lectures also add credibility to the teaching work, connecting the contents exposed in the subject with the business reality. This favors student motivation greatly. Martin et al. (1997) showed how credible teachers correlate with students with higher levels of motivation.

\section{Business environment simulations}

In some subjects, different simulations projects of real professional environments were designed, where students had to make decisions when faced with the arising situations. These simulations have been based on three widely known methodologies: self-learning (Rué, 2009), project-based learning 
Table 1

Activities carried out in the series of lectures during an academic year

\section{Activity}

Tools and alternatives for the financing of companies.

It brings students closer to the financing needs of companies and the real financial elements available to entrepreneurs.

Lecturers from Caja de Ingenieros

The economic control system.

Presentation of an engineering cost control system, emphasizing real cases of use.

Lecturers from Fundación Valentín de Madariaga y Oya.

Forum “La empresa Pública" ("Public companies").

Presentation of the work developed by engineers within two public companies.

Lecturers from RTVA and Puertos de Andalucía.

Forum "Casos de éxito en Lean Manufacturing" ("Lean Manufacturing Success Stories").

Presentations of real cases of application of the Lean Manufacturing methodology.

Lecturers from Atai Consulting, Renault and Airbus.

Mass Consumption supply chain

Lecture focused on three aspects: the context of Mass Consumption, the Supply Chain and the relevance of people's development.

Lecturer from Heineken.

Marketing and product management

Explanation of marketing concepts in a real case.

Lecturer from MP Elevators.

Online marketing: industry overview and introduction

Introduction to advertising on digital platforms and its management-negotiation.

Lecturer from Google (YouTube Spain)

Transition to active life

The main topic is the elaboration of the curriculum and preparation for the selection tests. The way in which to approach the selection processes from the candidate and the preparation of the interview.

Lecturer is a PhD. in Industrial Engineering from ETSI

Lectures on Good Engineering Practices.

Alumni who occupy top management positions analyse their beginnings in the business world and the aspects that are valued in an engineer.

Lecturers are alumni now working at H2B2, Clever, Ayesa, Airbus, Teams and Persan.

Innovation Management: from the University of Seville to Silicon Valley.

Product development experience, from university start-up to Silicon Valley (California).

Lecturer from INTEL Corporation.

\section{Entrepreneurship Forum}

"The vocation of entrepreneurship"

Lecturers from MP corporation.

"Entrepreneurship. Company culture",

Lecturers from Logística Integrada.

"Round table of experiences of entrepreneurship"

Lecturers from Atai Consulting, Aoifes, Dinami-k, Dinamicarea, Democracy and Racormance.

Certifications for project management

Presentation of the different possibilities of acquiring the necessary certifications for project management, such as PMP, Prince2 and Scrum/Agile. Lecturer from PMO Consultant

\section{Collaboration at the service of competitiveness}

Presentation of examples of collaboration between companies. The barcode case.

Lecturers from AECOC (Association of Manufacturers and Distributors)

Case study of project management: Lidl

Presentation of the management of a new Lidl store development project.

Lecturers from Lidl.

(Bell, 2010; Blumenfeld et al., 1991) and gamification (Presnky, 2001).

The main simulation activities carried out are shown below. All these activities were planned to be conducted in collaborative groups.

- Simulation of business start-up: In this activity, the objective was to create a company virtually. To do so, they had to develop a business idea, assess its acceptance, plan its development, study alternative legal forms for the company and seek financing.
- Development of an investment project: Students are provided with a real project, for which they have to make a cost analysis, seek financing and study the profitability of the operation.

- Project management: Several games were designed to simulate the management of a project. Certain risk parameters were included in these games. Search for financing.

- Improvement project using Lean methodologies: The students had to visit a company and make an analysis of waste in it. Proposals for improvements were issued 
and then assessed by company managers and a panel of professors.

- Development of cost accounting and balance analysis: The students, through the financial statements and the reports of the Economic Control System (cost accounting) must interpret the situation that a certain company is going through.

Some of these experiences have been described in detail in different publications (Escudero-Santana, 2015; Aparicio-Ruiz et al., 2019; Escudero-Santana et al., 2019; Montero et al., 2019).

\section{Results}

The results of this intervention were measured from 3 points of view. On the one hand, the satisfaction of the students with the developed activities (García-Berro et al. 2011), on the other hand, the improvement in the results and, finally, the perception of the professors and external lecturers (Pereira, 2011).

The satisfaction of the students was measured through surveys: both the compulsory one offered by the university and others administered ad-hoc in order to assess the activities carried out. All the subjects involved in the project had a rating above the average for the area and its degrees. Figure 1 shows the results obtained in the satisfaction surveys (out of 5) of the subjects that have participated in the project, as opposed to the average of the area, the degree and the University. Table 2 shows an ad-hoc survey carried out in the context of a subject related to business management to measure the assessment given by students with respect to these methodologies. The results show that students value this type of activity positively.

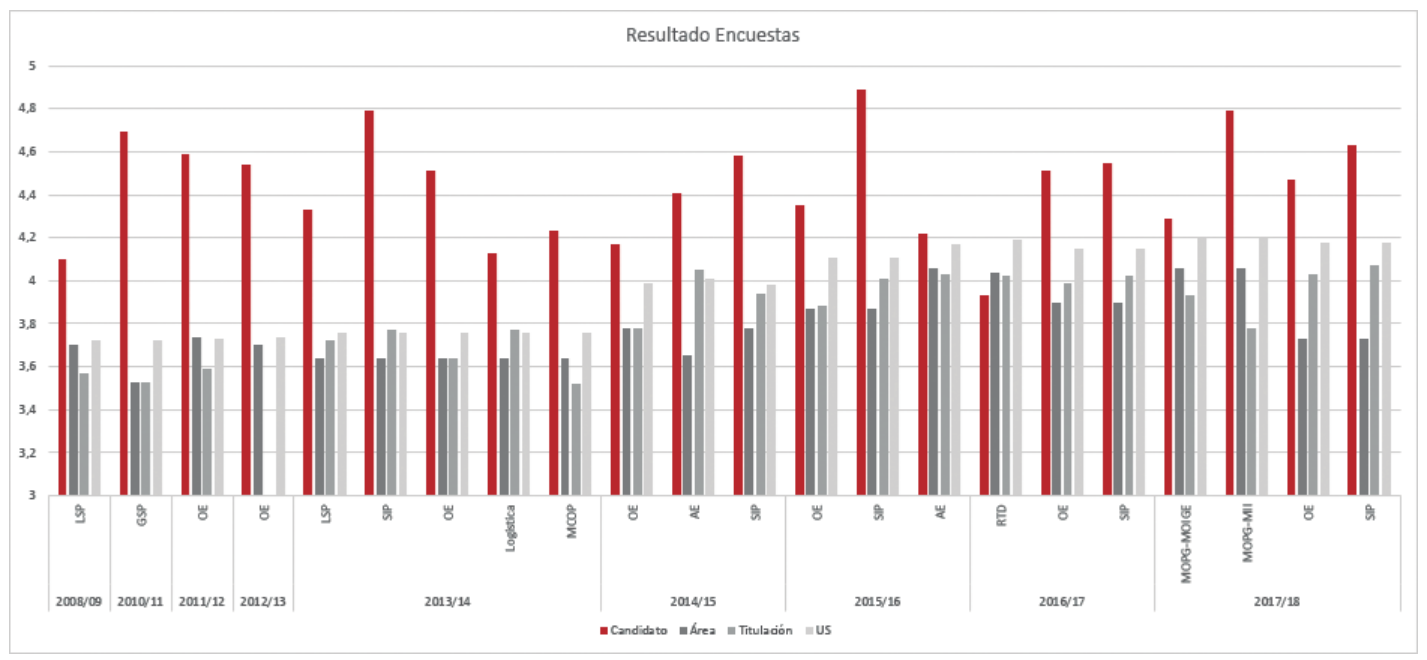

Figure 1. Satisfaction surveys of the subjects included in the project.

Table 2

Results of ad-hoc student survey.

\begin{tabular}{|c|c|c|c|c|c|}
\hline Question \Assesment & 1 & 2 & 3 & 4 & 5 \\
\hline Do you find lectures from professionals interesting? & 1 & 0 & 5 & 15 & 39 \\
\hline Have the lectures helped you to achieve the objectives of the course? & 1 & 3 & 2 & 20 & 34 \\
\hline Do you find the business simulation interesting? & 1 & 0 & 2 & 12 & 45 \\
\hline Has the business simulation helped you to achieve the objectives of the course? & 1 & 0 & 2 & 12 & 45 \\
\hline Would you consider it important to continue with this methodology? & 1 & 0 & 1 & 10 & 48 \\
\hline
\end{tabular}

Regarding the students' results, two important aspects should be mentioned: the student turnout rate and the final grade. In order to assess the impact of the intervention on this aspect, we have compared (see Figure 2) the results of the first call of two subjects in the field of business management whose teaching projects share many similarities, as they deal with the same contents, but in two different degrees. Subject 1 was part of the intervention, while subject 2, due to the number of students (see Figure 2a), did not participate fully. Analyzing the results shown in Figure $2 b$, it can be seen that the number of students not presented in subject 1 is significantly lower $(17 \%$ in subject 1 as opposed to $50 \%$ in subject 2). The same comparison can be established in the number of passing students in the first call.
The third aspect taken into account for the evaluation of this academic intervention was the perception of the professors and external lecturers. In order to carry out this measurement at the end of each course, a coordination meeting is set up where all the questions relating to the followed methodology are debated, and the feedback of the students and guest lecturers is analyzed. The main assessments obtained from these meetings have been:

- This type of activities has had a very positive evaluation. Students greatly value these activities, and their degree of involvement exceeds expectations.

- The external lecturers have highlighted the need to develop these activities, and their assessment of 

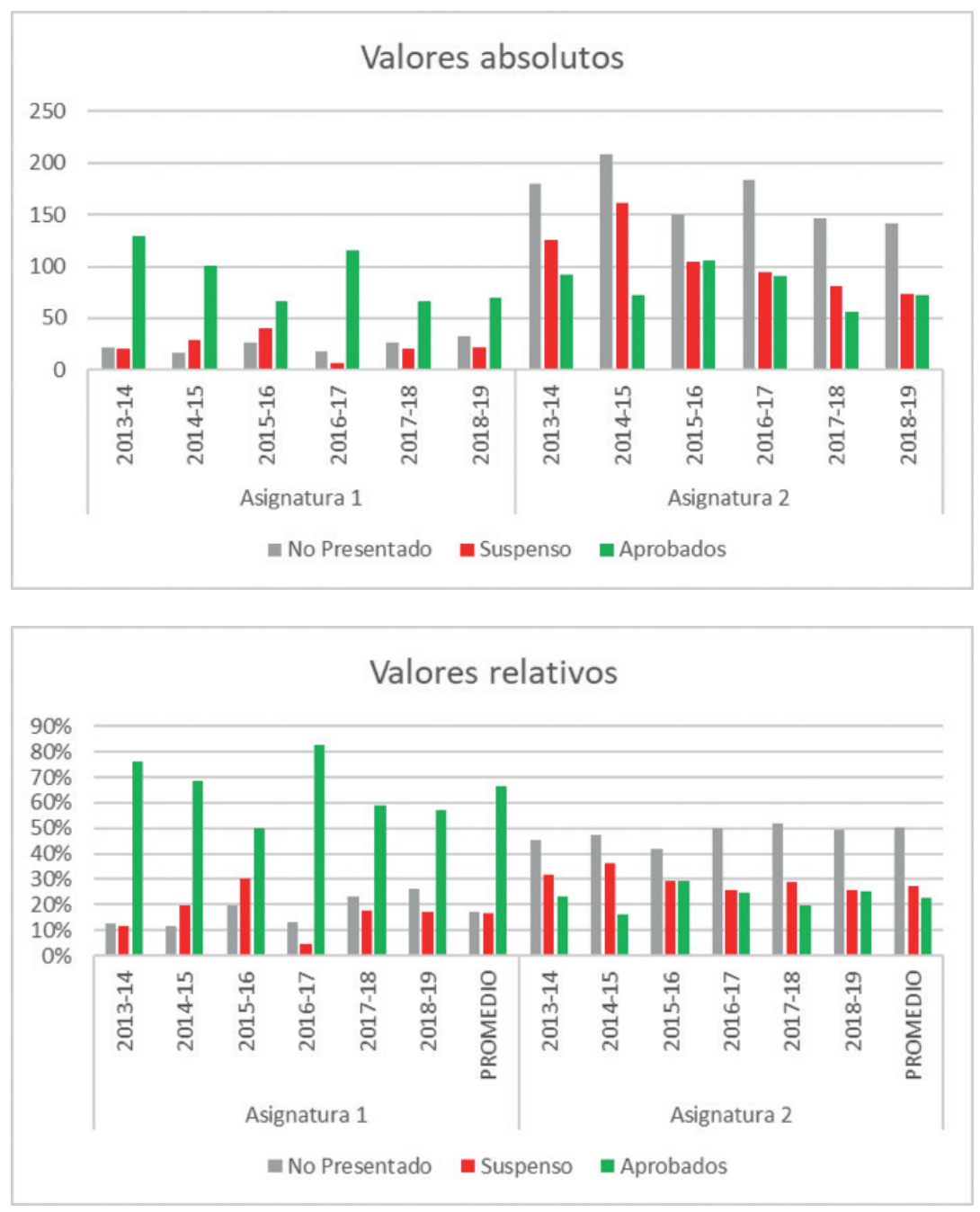

Figure 2. Comparison of results

the results achieved has been very positive. It is a generalized affirmation of the speakers that this type of activities greatly favors the training of students and their subsequent insertion in the labor market.

- The teachers have perceived a greater motivation of the students, which entails a greater implication with their own learning process.

- All the teachers involved in the intervention agree on the high temporal demand required by this type of activities. They make them impracticable, at least in full, when the group of students is very large.

\section{Conclusions}

In engineering degrees, subjects related to business management often face a general lack of motivation on the part of students. In order to reverse this situation, the Higher Technical School of Engineering is developing a teaching innovation project that links the contents of different subjects with real professional experiences. To this end, two types of activities have been designed: series of lectures that bring professionals closer to the classroom and business simulation projects, which seek a more practical and autonomous approach to the learning process.

The series of lectures features speakers of different kinds, who try to describe their professional experience and the needs of the market, from a multidisciplinary perspective. The lectures that are defined each year try to cover different areas, ranging from the development of skills less present in the curriculum of the degrees involved, to employability associated with new emerging technologies. These cycles have managed to motivate students in the need to be proficient in competences related to business management, allowing a greater predisposition of the student in the classroom.

Given that the most determining factor in the learning process is what the student does, teaching strategies that favored the active participation of the students were designed. Business simulation projects allowed students to develop deeper learning mechanisms, facilitating the interconnection of concepts.

The obtained results, both in terms of academic results and student satisfaction have been very positive, although they have not been free of difficulties. Both the degree of involvement of the students, reflected in an increase in the rate of submissions, and the academic results obtained, confirm this assertion.

\section{Referencias / References}

Accenture-Universia (2007). Las competencias profesionales en los titulados. Contraste y diálogo Universidad-Empresa.

Aparicio-Ruiz, P., Muñuzuri, J., Escudero-Santana, A., y Rodríguez-Palero, M. (2019) Bucket Brigades: simulation a 
production line in the classroom. En: Engineering Digital Transformation. Pp 151-158. Springer. 2019. DOI: 10.1007/9783-319-96005-0_19

Bell, S. (2010). Project-Based Learning for the 21st Century: Skills for the Future. The Clearing House: A Journal of Educational Strategies, Issues and Ideas, 83 (2), 39-43.

Blumenfeld, P.C., Soloway, E., Marx, R.W., Krajcik, J.S., Guzdial, M. y Palincsar, A. (1991). Motivating project-based learning: Sustaining the doing, supporting the learning. Educational psychologist, 26 (3-4), 369-98.

Escudero-Santana, A., Aparicio-Ruiz, P., Muñuzuri, J. y Madrigal, C. (2019) Gamificación en el aprendizaje de "lean manufacturing". Dirección y Organización 68. Pp. 51-65.

Escudero-Santana, A. (2015). Intervención en la asignatura organización de empresas del grado de ingeniería en tecnologías de telecomunicación mediante la aplicación de ciclos de mejora. II Jornada de Docencia Universitaria. 2 y 3 de julio 2015, Sevilla.

García-Berro, E., Colom, X., Martínez, E., Sallarés, J. y Roca, S. (2011). La encuesta al alumnado en la evaluación de la actividad docente del profesorado. Aula abierta 39 (3), 3-14.

Gil-Montoya C, Baños R, Gil-Montoya F, Alias A, Gil-Montoya MD (2007). Desarrollo de competencias en Ingeniería a través de metodologías activas. IV Jornadas Internacionales de Innovación Universitaria, Villaviciosa de Odón (Madrid), 12-13 de julio

Gil-Montoya, M.D., Herrada, R., Gil-Montoya F. y Alias, A. (2009). The Importance of Cooperative Work in the Faculty and in the Classroom. En W. Kouwenhoven (Ed.) Advances in Technology, Education and Development. InTech Europe, Rijeka
Martin, M.M., Chesebro, J.L., y Mottet, T.P. (1997). Student's perceptions of instructors' socio-communicative style and the influence on instructor credibility and situational motivation. Communication Research Report, 17, 431-440.

Montero, G., Cerezo-Narváez, A. y Otero-Mateo, M. (2019). Trabajando en proyectos con Lego Serious Play. Dirección y Organización. IN PRESS.

Mas-Tous, C. y Medinas-Amorós, M. (2007), Motivaciones para el estudio en universitarios. Anales de psicología, 23 (1), 17-24.

Paricio, J., Fernández, A. y Fernández, I. (2019) Cartografía de la buena docencia universitaria. Un marco para el desarrollo del profesorado basado en la investigación. Editorial Narcea.

Pereira, M. (2011) Nuevas tendencias en la evaluación de la calidad de las universidades: los índices de calidad percibida y satisfacción de los egresados (con modelos de ecuaciones estructurales). Aula abierta 39 (3), 73-84.

Perrenoud, P. (1998). Construir competencias desde la escuela. Santiago: Domen Ediciones.

Presnky, M. (2001). Digital Games-based Learning. McGraw Hill New York, London.

Rué, J. (2009). El aprendizaje autónomo en educación superior. Narcea Madrid.

Tuning Project (2009). Una introducción a Tuning Educational Structures in Europe. La contribución de las universidades al proceso de Bolonia. Bilbao: Publicaciones de la Universidad de Deusto.

Yániz, C. (2005). Las competencias en el currículo universitario: implicaciones para la formación del profesorado. REDU. Revista de Docencia Universitaria 4 (2) 21-29

Yániz, C. (2015). Las competencias genéricas como finalidad educativa. En L. Villardón-Gallego (Ed.) Competencias genéricas en educación superior. Metodologías específicas para su desarrollo (pp. 12-24) Madrid: Narcea. 